\title{
The role of PacC and Nuc-1 transcription factors in the microbial metabolic engineering
}

\section{Rodrigo da Silva Santos ${ }^{1,2}$, Ravely Casarotti Orlandelli ${ }^{3}$ and João Alencar Pamphile ${ }^{4}$}

${ }^{1}$ Laboratório de Patologia Molecular. Instituto de Ciências Biológicas (ICB2). Universidade Federal de Goiás (UFG). Av. Esperança, s/n. Campus Samambaia. Goiânia-GO. Brazil (CEP 74690-900). Email: rdssantos@gmail.com.

${ }^{2}$ Departamento de Ciências da Natureza (LEdoC). Unidade Acadêmica Especial de Ciências Humanas. Universidade Federal de Goiás (UFG). Praça Brasil Ramos Caiado, 35. Centro. Cidade de Goiás-GO. Brazil (CEP 76600-000).

${ }^{3}$ Colegiado de Ciências Biológicas. Faculdade Estadual de Educação, Ciências e Letras de Paranavaí. Universidade Estadual do Paraná (UNESPAR). Campus Paranavaí. Av. Gabriel Esperidião, s/n. Jardim Morumbi. Paranavaí-PR. Brazil (CEP87703-000).

${ }^{4}$ Laboratório de Biotecnologia Microbiana. Departamento de Biotecnologia, Genética e Biologia Celular. Universidade Estadual de Maringá (UEM). Av. Colombo, 5790. Jardim Universitário. Maringá-PR. Brasil (CEP 87020-900).
Abstract. The adaptation of microorganisms to different environmental conditions, such as temperature, salinity, extreme $\mathrm{pH}$ values, and oscillation in the availability of nutrients (carbon, nitrogen, and phosphate), has a vital role for their survival. The transduction of the signal generated by the sensing of the extracellular $\mathrm{pH}$ by fungi occurs through a conserved molecular pathway that involves the activation of PacC transcription factor. This adaptive response is observed in various species and impacts the metabolic processes, pathogenicity, and biotechnological applications in the industry. Variations in $\mathrm{pH}$ can influence nearly all physiological processes that lead to the secretion of macromolecules and metabolites. Under the influence of the regulatory circuits of carbon, nitrogen, sulfur, and $\mathrm{pH}$, the regulation of inorganic phosphate (Pi) uptake is performed by several regulatory genes, such as Nuc-1 transcription factor. Nuc-1 is involved with the post- transcriptional control and regulation of the transcription of structural genes that act in the homeostasis system and $\mathrm{Pi}$ uptake. Pi is essential for maintaining cell structure and many metabolic processes, being a growth limiter in nature. Thus, the genetic and molecular mechanisms that control the adaptation of microorganisms to the variations of Pi levels are being shown in many model organisms. In this way, the study of the adaptive microbial response to $\mathrm{Pi}$ oscillations has high importance, since these investigations may contribute to portray the regulation of molecular mechanisms involved with the $\mathrm{Pi}$ system and $\mathrm{pH}$ regulator circuit. The $\mathrm{pH}$ regulation, once established, will
Received
May 26, 2018
Accepted
August 10, 2018
Released
August 31, 2018
Full Text Article

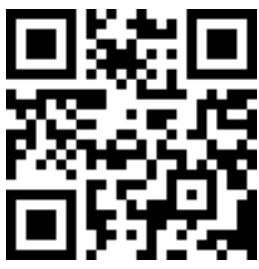
ORCID
(D) 0000-0002-9480-4362
Rodrigo da Silva Santos
(D) 0000-0002-1359-4210
Ravely Casarotti Orlandelli 
\begin{tabular}{l|l} 
permit the genetic manipulation of economic and medical & $\begin{array}{c}\odot 0000-0002-6139-5937 \\
\text { João Alencar Pamphile }\end{array}$
\end{tabular} processes.

Keywords: Environment pH; Phosphate; Transcription factors; metabolism.

\section{Introduction}

Microorganisms can adapt to environmental changes by regulating the gene expression in response to different ambient signals (Kato-Maeda et al., 2001). However, the mechanisms associated with gene expression regulation and metabolic modulation are intricate and still not fully understood. In the past few years, structural and functional genomic techniques were developed with the purpose to evaluate the differential gene expression of an organism or a cell. These highthroughput methods permit the detection of altered mRNA expression and chromosomal copy number variations in experimental conditions that mimic metabolic processes (Huang et al., 2007; Wise et al., 2007).

Fungi are microorganisms that can be free-living or saprophytic. These organisms play a fundamental role in food chains through organic matter decomposition. Several fungi species are pathogenic to humans and other animals, causing dermal and even systemic mycoses. Moreover, phytopathogens can negatively impact either the production and financial aspects of the farming industry. However, many fungi species have decisive economic importance (Murray et al., 2014; Schaechter et al., 2002), such as in the production of a high number of biotechnological products (Almeida et al., 2017; Orlandelli et al., 2017; Raj et al., 2015).

Microorganisms evolved in adverse environments where the competition was intense, and the presence of vital nutrients was scarce. In this way, the survival of these species was directly associated with the adaptation to environmental oscillations, such as temperature, salinity, $\mathrm{pH}$, and others. Moreover, the bioavailability of nutrients in the habitat of such species (carbon, nitrogen, and phosphate availability) also influences the development, biological activities, and the interaction of fungi and hosts, especially for pathogens (Santos, 2013).

To explore the economic potential and control the infections caused by fungal species, it is fundamental to elaborate the processes of environmental sensing, the pathways of physiological events that occur in function of this sensing, and the molecular mechanisms involved with the adaptive responses. The characterization of the metabolic reactions that control the homeostasis, sensing of the environment $\mathrm{pH}$, and nutrient intake (e.g., inorganic phosphate, $\mathrm{Pi}$ ) is vital to comprehend the developmental processes and survival of these microorganisms (Martinez-Rossi et al., 2011). Moreover, the homeostatic pH controls the growth, differentiation, and viability of all species, and that cells alter their metabolic responses in response to the abiotic factors present (FerreiraNozawa et al., 2006; Nozawa et al., 2003).

The microorganisms can adapt to the environmental $\mathrm{pH}$ by modulating their gene expression to adjust the adequate physiological conditions. The gene expression occurs in a coordinated manner in the cells in response to external and internal signals. Experimental data have confirmed that specific metabolic and pathogenic mechanisms rely directly or indirectly on the genes that monitor the extracellular pH (Ferreira-Nozawa et al., 2006; Luo et al., 2017; Nozawa et al., 2003). The adaptation to environmental changes, such as extracellular $\mathrm{pH}$ and $\mathrm{Pi}$ limitation have been extensively investigated in fungi as model organisms, in which the 
primary function is to characterize new biotechnological techniques.

In this review, we describe the biological role of PaCC and Nuc-1 in the fungal metabolic engineering, once both enzymes are extensively described in the literature as essential mediators of sensing and regulation of environmental $\mathrm{pH}$ and $\mathrm{Pi}$. In addition, the investigation of the fungi adaptability to environmental variations have been relevant to define of the mechanisms of pathogenicity and resistance to the inhibition of pathogenic organisms (Caddick et al., 1986; Dongliang et al., 2004; Nahas et al., 1982; Peleg et al., 1996).

\section{PacC transcription factor and the environmental pH}

The environmental $\mathrm{pH}$ is an essential factor of fungi physiology by influencing the transcription of many genes. In filamentous fungi and yeast, $\mathrm{PacC}$ is the transcription factor that regulates the expression of genes in acid or alkaline $\mathrm{pH}$ (Luo et al., 2017).

In 1965, by using a classical genetics approach, Dorn started the first studies on the regulation of gene expression in Aspergillus nidulans in response to the environmental $\mathrm{pH}$. These studies have shown that, in a condition of limited concentrations of phosphate and $\mathrm{pH}$ 6.5, mutations in the pal genes $(A, B$, $C$, and $F$ ) led to high levels of acid phosphatase and low levels of alkaline phosphatase. Conversely, mutations in pacC gene led to high levels of alkaline phosphatase and reduced acid phosphatase concentrations (Dorn, 1965).

In 1982, Ely Nahas, Héctor Francisco Terenzi, and Antonio Rossi described the adaptive response to $\mathrm{pH}$ in Neurospora crassa for the first time. The authors observed that the secretion, but not the synthesis of phosphatases, is $\mathrm{pH}$ dependent (Nahas et al., 1982). The involvement of $\mathrm{pal} / \mathrm{pacC}$ in the sensing of environmental $\mathrm{pH}$ by $A$. nidulans was described by Caddick, Brownlee and Arst (1986), which showed that the response to $\mathrm{pH}$ is mediated by a signaling pathway constituted of at least seven genes: pal $(A, B, C, F, H$, and I) and pacC (Santos, 2013).

In $A$. nidulans, the gene pacC encodes a transcription factor with 678 amino acids (72 KDa) and three zincfingers $\mathrm{Cis}_{2} \mathrm{His}_{2}$ that recognizes the consensus region 5'-GCCAR(A/G)G-3' in the promoter region of genes that respond to $\mathrm{pH}$. Further, it was proposed an environmental $\mathrm{pH}$ regulatory model in $A$. nidulans, in which the transcription factor PacC is responsible by the activation of the transcription of alkaline-specific genes and the repression of the transcription of acidspecific. This gene expression regulation is modulated by a signal generated by the products of the genes pal $(A, B, C, F, H$, and $I$ ) in response to the alkaline $\mathrm{pH}$ in a complex media (Freitas et al., 2011; Tilburn et al., 1995).

Experimental studies revealed that PacC transcription factor is maintained inactive in low $\mathrm{pH}$ by intramolecular interactions in its Cterminal end. In alkaline $\mathrm{pH}$, the products of pal genes introduce a structural modification that promotes the break of the intramolecular interactions and exposes a region of $\mathrm{PacC}$ protein to proteolysis, which makes this transcription factor active, functional and capable of inducing the transcription of alkaline genes and repressing the transcription of acid genes (Orejas et al., 1995). However, evidences show that the transcription factor PacC is functional in both acid and alkaline media, and that the molecular mechanisms involved in the regulation of gene expression by $\mathrm{pH}$ in $A$. nidulans rely on the nutritional conditions that the fungus is exposed to (Freitas et al, 2007, 2011; Rossi et al., 2013; Santos, 2013; Silva et al., 2008).

Sclerotinia sclerotiorum is a phytopathogen that can cause significant economic losses in farm cultures. The success of the infectious processes 
triggered by this filamentous fungus initially results in the synthesis and secretion of oxalic acid, which is dependent on the $\mathrm{pH}$ of the environment through PacC. A neutral or moderately alkaline host tissue stimulates the synthesis of oxalate, resulting in an acidification of the extracellular space. This process is a critical step for the differentiation between the saprophytic and necrotrophic growth. The secreted oxalate is toxic to the plant tissues and acts as a chelating agent of calcium ions, disrupting the biochemical system of the host by capturing the calcium from the cell wall, suppressing the oxidative stress generated by the neutralization of the reactive oxygen species, and reducing the affinity between the union of polygalacturonases of the fungus and the inhibitors of polygalacturonases of the host (Durman et al., 2005; Favaron et al., 2004; Rollins and Dickman, 2001; Santos, 2013).

To successfully colonize the host, microorganisms initially adhere to the target tissue and simultaneously obtain essential nutrients necessary for its growth. Fungi developed complex strategies to acquire micronutrients such as iron, while for many species the availability of this element is a signal for the induction of the expression of virulence factors. For instance, the excess of iron aggravates the meningitis condition in an animal model of a brain infection caused by the pathogen Cryptococcus neoformans. Moreover, recent studies revealed that the absorption of iron is regulated by a network of transcription factors, including PacC which acts in the regulation of genes involved with the maintenance of iron homeostasis, nutrient sensing, and cell wall (Kronstad et al., 2013).

In the pathogens Candida

albicans e $C$. neoformans, various genes that respond to the environmental $\mathrm{pH}$, including the pacC gene - which codifies a homologous protein of the PacC/Rim101p family of transcription factors that regulate $\mathrm{pH}$ - are directly associated with the pathogenicity of both species. In C. albicans, analysis of the Rim101 transcription factor revealed that there are significant differences on how rim101 is processed, the relative levels of activation or repression of gene transcription, and the genes regulated by rim101 when compared to its homologous Rim101 of Saccharomyces cerevisiae and PacC of A. nidulans. However, C. albicans improves its signaling pathway in response to $\mathrm{pH}$ to adapt to specific infection environments in human infections. In C. neoformans, the mutant lineage Cnrim101 is more sensitive to high $\mathrm{pH}$ and iron deprivation, two conditions present in the host. In addition, experimental models of cryptococcosis show that Cnrim101 lineage presents difficulties for capsule attachment, which is the primary virulence factor for this pathogenic fungus (Selvig and Alspaugh, 2011).

The dermatophyte Trichophyton rubrum presents a PacC homologous protein whose genetic inactivation showed that the development of keratin and consequent degradation of this molecule are likely associated with the regulation of pacC. This function interferes in the secretion and activity of proteases that present the optimum activity in alkaline pH (Ferreira-Nozawa et al., 2006; Martinez-Rossi et al., 2017; Peres et al., 2010). The transcription factor PacC is presumably linked to the virulence of the dermatophyte T. rubrum since this species mobilizes enzymatic machinery in function of the environment $\mathrm{pH}$ to establish an infection. Moreover, the recruited enzymes are proteases that are active in a wide range of $\mathrm{pH}$.

In 2004, a model of the regulation of proteolytic enzymes by environmental $\mathrm{pH}$ during the infection by dermatophytes was proposed. At the initial stages of the infection, the pathogen, when exposed to the low $\mathrm{pH}$ of the skin, starts synthesizing unspecific keratinases and proteases that have a 
high performance at low $\mathrm{pH}$. These enzymes act in keratin and non-keratin substrates to generate peptides, which are hydrolyzed in amino acids that will be used as carbon, nitrogen, and sulfur source. The metabolization of some amino acids, such as glycine, result in the release of ammonia, which increases the $\mathrm{pH}$ of the environment and adjusts it for the action of the keratinases with optimal activity in alkaline $\mathrm{pH}$. The increase of $\mathrm{pH}$ then maintains the infection. This metabolic machinery permits that the dermatophytes use the proteins as uptake of nutrients in a wide range of $\mathrm{pH}$, enabling the complete installation, development, and survival of the dermatophyte in the host's tissue (Martinez-Rossi et al., 2004, 2011, 2017).

Recently, functional genomic investigations using the mutant lineage pacC-1 have shown that PacC transcriptional factor acts directly or indirectly in the regulation of the expression of many genes that are related to the survival, pathogenicity and adaptative response to $\mathrm{pH}$ by T. rubrum. The identified genes have essential biological functions, from basic cell demand to protein glycosylation, which is a process that maintains the cell wall integrity and influences the virulence of some fungi species, since these enzymes also impact the adhesion of the organism in the host's cells (Cazzaniga, 2011; Mendes et al., 2012; Santos, 2013).

\section{Nuc-1 transcription factor and phosphate homeostasis}

$\mathrm{Pi}$ is an essential nutrient for all organisms, being necessary for the structure and growth of cells, metabolic responses, nucleic acid synthesis, membrane phospholipids, and a component of several cell metabolites (Paytan and McLaughlin, 2007). In this way, the phosphate uptake from the environment in both prokaryotic and primitive eukaryotic organisms is one of the most critical processes for nutrient acquisition (Furukama et al., 1987). The fungi $N$. crassa and S. cerevisiae are used as biological models for experimental studies that aim to comprehend the molecular mechanisms that are initiated by variations of the environmental $\mathrm{Pi}$ concentration. In these species, the cell acquisition, supply, liberation, and metabolic integration of Pi rely on the function of various enzymes, such as nucleases, acid and alkaline phosphatases, permeases, and others, whose expression is dependent on the intracellular Pi levels (Ogawa et al., 2000; Peleg et al., 1996; Persson et al., 2003; Santos, 2013).

When the filamentous fungus $N$. crassa is cultivated in a media containing limited quantities of $\mathrm{Pi}$ or with nucleic acids as unique Pi source, many enzymes are synthesized to provide more phosphate to the cell. In response to this limitation, $N$. crassa and all other living organisms synthesize phosphatases, nucleases, and phosphate permeases to meet the intracellular demand of this nutrient (Metzenberg and Chia, 1979; Nahas et al., 1982). When Pi is deficient, the phosphatases are synthesized and secreted in the environment. Some studies have shown that the extracellular $\mathrm{pH}$ is determinant for the secretion of Pi-repressible phosphatases, such as alkaline phosphatase codified by the gene pho-2 (Grotelueschen et al., 1994), which is preferably secreted when the environment $\mathrm{pH}$ is 8.0 (Nahas et al., 1982; Nozawa et al., 2002). However, in $S$. cerevisiae, the induction of several genes in alkaline $\mathrm{pH}$ occurs through independent mechanisms of the signaling pathway mediated by PacC (Lamb et al., 2001). In N. crassa, even though pho-2 gene is also induced in acid and alkaline $\mathrm{pH}$, the stable and active form of the enzyme is predominantly secreted in alkaline $\mathrm{pH}$, in a process that is glycosylation-dependent (Han et al., 1987; Palma et al.,1989; Thedei Junior et al., 1997).

The molecular mechanisms involved in the sensing of phosphate and 
the cellular signaling to the biosynthesis of enzymes and permeases engaged in the Pi homeostasis were well established in $N$. crassa by genetic and biochemical approaches. These studies revealed that the mechanism that occurs in response to $\mathrm{Pi}$ is mediated by at least four regulatory genes: nuc-1, nuc-2, preg and pgov (Metzenberg and Chia, 1979). These genes are highly conserved in $N$. crassa and S. cerevisiae (Davis, 2000).

Leal et al. (2007) proposed a modification to the model of regulation of phosphate acquisition in $N$. crassa that was previously published by Merzenberg in 1979. According to the new model, the action of the product of nuc-1 gene allows the expression of structural genes involved with the capitation of Pi. The effect of Nuc-1 is antagonized by the products of genes preg and pgov, which are antagonized by Nuc- 2 . The product of gene nuc-2 is the component that transduces the activation signal of this regulatory circuit, and its action is inhibited by Pi or a co-repressor derived from Pi. Accordingly, in low concentrations of $\mathrm{Pi}$, Nuc-2 inhibits the function of the complex PREG-PGOV and activates the Nuc-1 transcription factor and the expression of acid and alkaline phosphatases, phospho-permeases, nucleases, and others. Thus, Leal et al. (2007) described that the genes nuc-1, nuc-2, preg and pgov play a role in the control of post-transcriptional modifications and secretion of phosphatases in addition to the regulation of structural genes of these systems (Metzenberg, 1979; Leal et al., 2007). Recently, it was shown that a MAP kinase (MAPK-2) is also a component of this pathway, presumably by interacting with the complex PREG-PGOV in repressive conditions, such as high extracellular concentrations of Pi (Gras et al., 2013; Santos, 2013).

The nuc-1 gene is constitutively expressed, independently of the concentrations of $\mathrm{Pi}$. In addition, the activity of the Nuc-1 protein is positively regulated in limited levels of $\mathrm{Pi}$, as Nuc-1 promotes the activation of alkaline phosphatases repressed by $\mathrm{Pi}$ and phosphate permeases (Kang and Metzenberg, 1990). The Nuc-1 transcription factor is composed of approximately 802 amino acids in addition to having a functional alkaline domain in its carboxy-terminal region. This domain presents a DNA binding motif type basic helix-loop-helix (bHLH), which is present in a high number of transcription factors involved with various cellular processes, such as differentiation, development, proliferation, and response to stress. The bHLH transcription factors bind to $5^{\prime}$ CACGTG-3' consensus sequences and form dimers or combinations of heterodimers with other bHLH proteins (Peleg and Metzenberg, 1994; Chen and Lopes, 2007).

The Nuc- 1 transcription factor is considered as an atypical HLH protein, as presents structural variations when compared to other HLH transcription factors. Moreover, Nuc-1 has a dimerization domain constituted by a zipper motif, present also in other HLH proteins characterized as $\mathrm{HLH} / \mathrm{Z}$. The zipper motif of Nuc-1 is formed by alanine and methionine repeated sequences instead of leucine, as commonly found in $\mathrm{HLH} / \mathrm{Z}$ proteins. In addition, the helix II and zipper domains of Nuc- 1 are crucial for the dimerization of this protein, while the helix I domain is involved with DNA binding (Peleg and Metzenberg, 1994). Recently, it was shown that Nuc-1 presents functional domains that are potentially involved with the interaction with the negative regulator factors PREG/PGOV and transcriptional activity (Santos, 2013).

C. albicans is an opportunistic pathogen that can proliferate in the intestinal tract of critically immunocompromised patients, being one of the major responsible for infectious diseases caused by fungi. Experimental studies with functional analyses of the mutant lineage pho4 of $C$. albicans revealed that this lineage is 
more virulent when compared to the wild-type. This increased virulence occurs since the absence of $\mathrm{PHO} 4$ protein stimulates the filamentation in response to the limitation of $\mathrm{Pi}$, indicating the role of pho genes in the absorption and utilization of Pi during the infection. The capacity to capture the Pi benefits fungus species to compete with the standard microbiota and represents an ability to adapt to an environment that lacks nutrients (Romanowski et al., 2012). Although investigations have shown promising findings regarding the adaptive response and sense of fungi to the levels of $\mathrm{Pi}$, the molecular mechanisms involved with the regulation of Nuc-1 expression in response to different nutrient sources and its role on pathogenicity, adaptability, and infectibility of pathogenic fungi remain inconclusive (Santos, 2013).

\section{Final considerations}

The success of modern genomics with the cloning and sequencing of pacC and pals genes - the first established genes that are potentially associated with the signal transduction generated by extracellular $\mathrm{pH}$ - permitted the advance of the functional molecular studies of the adaptive responses. The molecular and metabolic mechanisms in the adaptive response to the monitoring of the extracellular $\mathrm{pH}$ and the regulation of the homeostatic $\mathrm{pH}$ have been highlighted since organisms rigorously control their cell $\mathrm{pH}$. The acidification of the steps that lead to exocytosis, pinocytosis, and phagocytosis, as well as the relative implications to the metabolic processes are essential for the efficiency of cellular contractile elements (actin, myosin, and microtubules) and the conductibility of ionic channels. In addition, the oscillations of the intracellular $\mathrm{pH}$ influence the control of the cell cycle and proliferation. The implication of homeostatic $\mathrm{pH}$ in several cellular processes are vast and complex, in a way that the knowledge obtained from research have been applied in the therapeutics, such as control of bacterial and fungus infections, investigations in the interaction between mechanisms that control intracellular $\mathrm{pH}$, action of antimicrobial drugs, and control of the growth and death of tumor cells.

$$
\text { Virtually all physiological }
$$

processes that lead to the secretion of macromolecules and metabolites by any living organism can rely on the adaptive response to extracellular $\mathrm{pH}$, such as the secretion of penicillin by $A$. nidulans. This observation reveals the economic importance that the regulation of $\mathrm{pH}$ can have, once all industrial fermentation processes could be manipulated at the genetic level when the molecular basis of these processes are elucidated.

Similarly, to $\mathrm{pH}$, the homeostasis and Pi intake mediated by Nuc-1 is also critical to various cell processes, influencing growth, physiology, and cell differentiation. The control of $\mathrm{Pi}$ acquisition by the cell is essential since this nutrient is used for the synthesis of nucleic acids (RNA and DNA), proteins, lipids, and carbohydrates. The complexity of the regulation of Pi system is a valuable tool for understanding gene regulation, cell cycle, substrate transport, nutrient monitoring, integration between cell response and environmental changes, and regulation of the subcellular localization through phosphorylation.

\section{Acknowledgments}

We are grateful to the Brazilian funding agency $\mathrm{CNPq}$ and CAPES for financial support.

\section{Conflict of interests}

The authors declare that there are no conflicts of interest.

\section{References}

Almeida, T. T.; Ribeiro, M. A. S.; Polonio, J. C.; Garcia, F. P.; Nakamura, C. V.; Meurer, E. C.; 
Sarragiotto, M. H.; Baldoqui, D. C.; Azevedo, J. L.; Pamphile, J. A. Curvulin and spirostaphylotrichins $\mathrm{R}$ and $\mathrm{U}$ from extracts produced by two endophytic Bipolaris sp. associated to aquatic macrophytes with antileishmanial activity. Natural Product Research, v. 26, p. 1-8, 2017. https://doi.org/10.1080/14786419.2017.13 80011

Caddick, M. X.; Brownlee, A. G.; Arst, H. N. Regulation of gene-expression by $\mathrm{pH}$ of the growth-medium in Aspergillus nidulans. Molecular Genetics and Genomics, v. 203, no. 2, p. 346-353, 1986. https://doi.org/ $10.1007 / \mathrm{bf00333978}$

Cazzaniga, R. A. Caracterização funcional do fator de transcrição Pacc do dermatófito Trichophyton rubrum: regulação da expressão gênica em resposta ao pH ambiente e na interação com moléculas do hospedeiro. São Paulo: Universidade de São Paulo, 2011. (Thesis of doctorat). Available from: <http://bdpi.usp.br/item/002198772>.

Accessed on: Nov. 01, 2017.

Chen, M.; Lopes, J. M. Multiple basic helixloop-helix proteins regulate expression of the ENO1 gene of Saccharomyces cerevisiae. Eukaryotic Cell, v. 6, no. 5, p. 786-796, 2007. https://doi.org/10.1128/EC.00383-06

Davis, R. H. Neurospora: Contributions of a model organism. New York: Oxford University Press, 2000.

Dongliang, W.; Dou, X.; Hashmi, S. B.; Osmani, S. A. The Pho80-like cyclin of Aspergillus nidulans regulates development independently of its role in phosphate acquisition. Journal of Biological Chemistry, v. 279 , no. 36 , p. 37693-37703, 2004. https://doi.org/10.1074/jbc.M4038 53200

Dorn, G. Phosphatase mutants in Aspergillus nidulans. Science, v. 150 , no. 1, p. 1183-1184, 1965. https://doi.org/10.1126/science.150. 3700.1183

Durman, S. B.; Menendez, A. B.; Godeas, A. M. Variation in oxalic acid production and mycelial compatibility within field populations of Sclerotinia sclerotiorum. Soil Biology and Biochemistry, v. 37, no. 1, p. 2180-2184, 2005. https://doi.org/ 10.1016/j.soilbio.2005.03.017

Favaron, F.; Sella, L.; D'Ovidio, R. Relationships among endopolygalacturonase, oxalate, $\mathrm{pH}$, and plant polygalacturonase-inhibiting protein (PGIP) in the interaction between Sclerotinia sclerotiorum and soybean. Molecular PlantMicrobe Interactions, v. 17, no. 12, p. 14021409, 2004. https://doi.org/10.1094/ mpmi.2004.17.12.1402

Ferreira-Nozawa, M. S.; Silveira, H. C.; Ono, C. J.; Fachin, A. L.; Rossi, A.; Martinez-Rossi, N. $\mathrm{M}$. The $\mathrm{pH}$ signaling transcription factor PacC mediates the growth of Trichophyton rubrum on human nail in vitro. Medical Mycology, v. 44, no. 7, p. $641-645,2006$. https://doi.org/10.1080/136937806008765 53

Freitas, J. S.; Silva, E. M.; Rossi, A. Identification of nutrient-dependent changes in extracellular $\mathrm{pH}$ and acid phosphatase secretion in Aspergillus nidulans. Genetics and Molecular Research, v. 6, no. 3, p.721-729, 2007. Available from: <http://www.funpecrp.com.br/gmr/year200 7/vol3-6/gmr0369_abstract.html>. Accessed on: Nov. 01, 2017.

Freitas, J. S.; Silva, E. M.; Leal, J.; Gras, D. E.; Martinez-Rossi, N. M.; Santos, L. D.; Palma, M. S.; Rossi, A. Transcription of the Hsp30, Hsp70, and Hsp90 heat shock protein genes is modulated by the PalA protein in response to acid pH-sensing in the fungus Aspergillus nidulans. Cell Stress and Chaperones, v. 16, no. 15, p.565-572, 2011. https://doi.org/ 10.1007/s12192-011-0267-5

Furukama, K.; Hasunuma, K.; Shinohara, Y. Characterization of Pi-repressible enzymes secreted in culture media by Neurospora crassa wild-type cells and null type mutants. Journal of Bacteriology, v. 169, no. 10, p. 4790-4795, 1987. https://doi.org/ 10.1128/jb.169.10.4790-4795.1987

Gras, D. E.; Persinoti, G. F.; Peres, N. T. A.; Martinez-Rossi, N. M.; Tahira, A. C.; Reis, E. M.; Prade, R. A.; Rossi, A. Transcriptional profiling of Neurospora crassa $\Delta m a k-2$ reveals that mitogen-activated protein kinase MAK-2 participates in the phosphate signaling pathway. Fungal and Genetics Biology, v. 60, no. 1, p.140-149, 2013. https://doi.org/10.1016/j.fgb.2013.05.007

Grotelueschen J.; Peleg, Y.; Glass, N. L; Metzenberg, R. L. Cloning and characterization of the pho-2+ gene encoding a repressible alkaline phosphatase in Neurospora crassa. Gene, v. 144, no. 1, p. $147-$ 148, 1994. https://doi.org/10.1016/03781119(94)90223-2 
Han, S. W.; Nahas, E.; Rossi, A. Regulation of synthesis and secretion of acid and alkaline phosphatases in Neurospora crassa. Current Genetics, v. 11, no. 6-7, p. 521-527, 1987. https://doi.org/10.1007/bf00384615

Huang X.; Li Y.; Niu Q.; Zhang K. Suppression Subtractive Hybridization (SSH) and its modifications in microbiological research. Applied Microbiology and Biotechnology, v. 76, no. 4, p. 753-760, 2007. https://doi.org/10.1007/s00253-007-10768

Kang, S.; Metzenberg, R. L. Molecular analysis of nuc-1+, a gene controlling phosphorus acquisition in Neurospora crassa. Molecular and Cellular Biology, v. 10 , no. 11, p. 58395848, 1990. https://doi.org/10.1128/ mcb.10.11.5839

Kato-Maeda, M.; Gao Q.; Small, P. M. Microarray analysis of pathogens and their interaction with hosts. Cellular and Microbiology, v. 3, n. 11, p. 713-719, 2001. https://doi.org/10.1046/j.1462-5822.2001. 00152.x

Kronstad J. W.; Hu, G.; Jung, W. H. An encapsulation of iron homeostasis and virulence in Cryptococcus neoformans. Trends in Microbiology, v. 21, no. 9, p. 457465, 2013. https://doi.org/10.1016/j.tim. 2013.05.007

Lamb, T. M.; Xu, W.; Diamond, A.; Mitchell, A. P. Akaline response genes of Saccharomyces cerevisiae and their relationship to the RIM101 pathway. Journal of Biological Chemistry, v. 276, no. 3, p. 1850-1856, 2001. https://doi.org/10.1074/jbc.M008381200

Leal, J. Squina, F. M.; Martinez-Rossi, N. M.; Rossi, A. The transcription of the gene for isoorotate decarboxylase (IDCase), an enzyme of the thymidine salvage pathway, is downregulated in the pregc $^{c}$ mutant strain of Neurospora crassa grown under phosphate starvation. Canadian Journal of Microbiology, v. 53, no. 8, p.1011-1015, 2007. https://doi.org/10.1139/W07-064

Luo Z.; Ren, H.; Mousa, J. J.; Rangel, D. E.; Zhang, Y.; Bruner, S. D.; Keyhani, N. O. The PacC transcription factor regulates secondary metabolite production and stress response, but has only minor effects on virulence in the insect pathogenic fungus Beauveria bassiana. Environmental Microbiology, v. 19, no. 2, p. 788-802, 2017. https://doi.org/10.1111/ 1462-2920.13648
Martinez-Rossi, N. M.; Ferreira-Nozawa, M. S.; Graminha, M. A. S; Nozawa, S. R.; Fachin, A. L.; Cervelatti, E. P.; Prade, R. A.; Rossi, A. Molecular aspects of dermatophyte-host interactions. In: Kushwaha, R. K. S. (Ed.). Fungi in human and animal health. 9. ed. Jodhpur, India: Scientific Publishers, 2004. p. 143-165.

Martinez-Rossi, N. M.; Persinoti, G. F.; Peres, N. T. A.; Rossi, A. Role of $\mathrm{pH}$ in the pathogenesis of dermatophytoses. Mycoses, v. 55, no. 5, p. 381-387, 2011. https://doi.org/10.1111/j.1439-0507.2011. 02162.x

Martinez-Rossi, N. M.; Peres N. T.; Rossi A. Pathogenesis of dermatophytosis: sensing the host tissue. Mycopathologia, v. 182, no. $1 / 2$, p. $215-227,2017$. https://doi.org/ 10.1007/s11046-016-0057-9

Mendes, N. S.; Trevisan, G. L.; Cruz, A. H. S.; Santos, R. S.; Peres, N. T. A.; Martinez-Rossi, N. M.; Rossi, A. Transcription of $\mathrm{N}$ - and $\mathrm{O}$ linked mannosyltransferase genes is modulated by the pacC gene in the human dermatophyte Trichophyton rubrum. FEBS Open Bio, v. 2, no. 1, p. 294-297, 2012. https://doi.org/10.1016/j.fob.2012.09.005

Metzenberg, R. L. Implications of some genetic control mechanisms in Neurospora. Microbiological Reviews, v. 43, no. 3, p.361-383, 1979. Available from: <http://mmbr.asm.org/content/43/3/361.lo ng>. Accessed on: Nov. 01, 2017.

Metzenberg, R. L.; Chia, W. Genetic control of phosphorus assimilation in Neurospora crassa: dose-dependent dominance and recessive ness in constitutive mutants. Genetics, v. 93, no. 3, p.625-643, 1979. Available from: <http://www.genetics.org/ content/93/3/625.long>. Accessed on: Nov. 01, 2017.

Murray, P. R. Microbiologia Médica. Rio de Janeiro: Guanabara Koogan, 2014.

Nahas, E.; Terenzi, H. F.; Rossi, A. Effect of carbon source and $\mathrm{pH}$ on the production and secretion of acid-phosphatase (EC3.1.3.2) and alkaline-phosphatase (EC3.1.3.1) in Neurospora crassa. Journal of General Microbiology, v. 128, no. 9, p. 2017-2021, 1982. https://doi.org/10.1099/00221287128-9-2017

Nozawa, S. R.; Thedei, G.; Crott, L. S. P.; Barbosa, J. E.; Rossi, A. The synthesis of phosphate-repressible alkaline phosphatase does not appear to be regulated by ambient 
$\mathrm{pH}$ in the filamentous mould Neurospora crassa. Brazilian Journal of Microbiology, $\begin{array}{llll}\text { v. 33, no. } 1, \quad \text { p. } 92-95, & 2002 .\end{array}$ http://dx.doi.org/10.1590/S1517-838220 02000100018

Nozawa, S. R.; Ferreira-Nozawa, M. S.; Martinez-Rossi, N. M.; Rossi, A. The pHinduced glycosylation of secreted phosphatases is mediated in Aspergillus nidulans by the regulatory gene pacCdependent pathway. Fungal Genetics and Biology, v. 39, no. 3, p. 286-295, 2003. https://doi.org/10.1016/S1087-1845(03) 00051-3

Ogawa, N.; Derisi, J.; Brown, P. O. New components of a system for phosphate accumulation and polyphosphate metabolism in Saccharomyces cerevisiae revealed by genomic expression analysis. Molecular Biology of the Cell, v. 11 , no. 12, p. 43094321, 2000. https://doi.org/10.1091/ mbc.11.12.4309

Orejas, M.; Espeso, E. A.; Tilburn, J.; Sarkar, S.; Arst, H. N. Jr.; Peñalva, M. A. Activation of the Aspergillus PacC transcription factor in response to alkaline ambient $\mathrm{pH}$ requires proteolysis of the carboxy-terminal moiety. Genes and Development, v. 9, no. 13, p. 1622-1632, 1995. https://doi.org/ 10.1101/gad.9.13.1622

Orlandelli, R. C.; Corradi da Silva, M. L.; Vasconcelos, A. F. D.; Almeida, I. V.; Vicentini, V. E. P.; Prieto, A.; Hernandez, M. D. D.; Azevedo, J. L.; Pamphile, J. A. $\beta-(1 \rightarrow 3,1 \rightarrow 6)-D-$ glucans produced by Diaporthe sp. endophytes: purification, chemical characterization and antiproliferative activity against MCF-7 and HepG2-C3A cells. International Journal of Biological Macromolecules, v. 94, p. 431-437, 2017. https://doi.org/10.1016/j.ijbiomac.2016.10. 048

Palma, M. S.; Han, S. W.; Rossi, A. Dissociation and catalytic activity of phosphaterepressible alkaline-phosphatase from Neurospora crassa. Phytochemistry, v. 28, no. 12, p. 3281-3284, 1989. https://doi.org/ 10.1016/0031-9422(89)80331-0

Paytan, A.; Mclaughlin, K. The oceanic phosphorus cycle. Chemical Reviews, v. 107, no. 12 , p. 563-576, 2007. https://doi.org/ $10.1021 / \mathrm{cr} 0503613$

Peleg, Y.; Metzenberg, R. L. Analysis of the DNA-binding and dimerization activities of Neurospora crassa transcription factor
NUC-1. Molecular and Cellular Biology, v. 14, no. 12, p.7816-7826, 1994. https://doi.org/10.1128/mcb.14.12.7816

Peleg, Y.; Aramayo, R.; Kang, S.; Hall, J. G.; Metzenberg, R. L. NUC-2, a component of phosphate-regulated signal transduction pathway in Neurospora crassa, is an ankyrin repeat protein. Molecular and General Genetics, v. 252, no. 6, p. 709-716, 1996. https://doi.org/10.1007/bf02173977

Peres, N. T.; Maranhão, F. C.; Rossi, A.; Martinez-Rossi, N. M. Dermatophytes: hostpathogen interaction and antifungal resistance. Anais Brasileiros de Dermatologia, v. 85, no. 5, p. 657-667, 2010. https://doi.org/10.1590/S0365-0596201 0000500009

Persson, B. L.; Lagerstedt, J. O.; Pratt, J. O.; Pattison-Granberg, J.; Lundh, K.; Shokrollahzadeh, S.; Lundh, F. Regulation of phosphate acquisition in Saccharomyces cerevisiae. Current Genetics, v. 43, no. 4, p. 225-244, 2003. https://doi.org/10.1007/ s00294-003-0400-9

Raj, K G.; Manikandan, R.; Arulvasu, C.; Pandi, M. Anti-proliferative effect of fungal taxol extracted from Cladosporium oxysporum against human pathogenic bacteria and human colon cancer cell line HCT 15. Spectrochimica Acta Part A: Molecular and Biomolecular Spectroscopy, v. 138, p. 667-674, 2015. https://doi.org/10.1016/ j.saa.2014.11.036

Rollins, J. A.; Dickman, M. B. pH Signaling in Sclerotinia sclerotiorum: Identification of a pacC/RIM1 Homolog. Applied and Environmental Microbiology, v. 67, no. 1, p. 75-81, 2001. https://doi.org/10.1128/ aem.67.1.75-81.2001

Romanowski K.; Zaborin, A.; Valuckaite, V.; Rolfes, R. J.; Babrowski, T.; Bethel, C.; Olivas, A.; Zaborina, 0.; Alverdy, J. C. Candida albicans isolates from the gut of critically ill patients respond to phosphate limitation by expressing filaments and a lethal phenotype. Plos One, v. 7, n. 1, p. 301-319, 2012. https://doi.org/10.1371/journal.pone.00301 19

Rossi, A.; Cruz, A. H. S.; Santos, R. S.; Silva, P. M.; Silva, E. M.; Mendes, N. S.; Martinez-Rossi. Ambient $\mathrm{pH}$ sensing in filamentous fungi: pitfalls in elucidating regulatory hierarchical signaling networks. International Union of Biochemistry and Molecular Biology Life, 
v. $65, \quad$ no. $11, \quad$ p. $930-935, \quad 2013$. https://doi.org/10.1002/iub.1217

Santos, R. S. Regulação da expressão gênica no patógeno humano Trichophyton rubrum em resposta ao $\mathrm{pH}$ ambiente, a variações nutricionais e na interação dermatófito-hospedeiro. São Paulo: Universidade de São Paulo, 2013. (Thesis of doctorat). https://doi.org/10.11606/ T.17.2013.tde-15052014-104035

Schaechter, M. Microbiologia: mecanismos das doenças infecciosas. Rio de Janeiro: Guanabara Koogan, 2002.

Selvig, K.; Alspaugh, J. A. pH response pathways in fungi: adapting to host-derived and environmental signals. Mycobiology, v. 39, no. 4, p. 249-256, 2011. https://doi.org/10.5941/myco.2011.39.4.24 9

Silva, E. M.; Freitas, J. S.; Gras, D. E.; Squina, F. M.; Leal, J.; Silveira, H. C.; Martinez-Rossi, N. M.; Rossi, A. Identification of genes differentially expressed in a strain of the mold Aspergillus nidulans carrying a lost-offunction mutation in the palA gene.
Canadian Journal of Microbiology, v. 54, no. 10, p. 803-811, 2008. https://doi.org/ 10.1139/w08-072

Thedei-Júnior, G.; Nozawa, S. R.; Simões, A. L.; Rossi, A. Gene pho-2 codes for the multiple active forms of Pi-repressible alkaline phosphatase in the mould Neurospora crassa. World Journal of Microbiology and Biotechnology, v. 13, no. 1, p. 609-611, 1997. https://doi.org/10.1023/A:1018550317025

Tilburn, J.; Sarkar, S.; Widdick, D. A.; Espeso, E. A.; Orejas, M.; Mungroo, J.; Peñalva, M. A.; Arst, H. N. Jr. The Aspergillus PacC zinc finger transcription factor mediates regulation of both acid- and alkaline-expressed genes by ambient pH. EMBO Journal, v. 14, no. 4, p. 779-790, 1995. https://doi.org/10.1002/ j.1460-2075.1995.tb07056.x

Wise, R. P.; Moscou, M. J.; Bogdanove, A. J.; Whitham, S. A. Transcript profiling in hostpathogen interactions. Annual Review of Phytopathology, v. 45, no. 1, p. 329-369. 2007. https://doi.org/10.1146/annurev. phyto.45.011107.143944 